DOI : $10.14746 /$ rie.2015.9.36

\title{
Normatywna potęga Unii Europejskiej w obliczu konfliktów między- narodowych, red. Anna Skolimowska, Dom Wydawniczy Elipsa, Warszawa 2015, ss. 226.
}

Recenzowana publikacja stanowi autorską, oryginalną próbę weryfikacji teoretycznej koncepcji roli Unii Europejskiej w stosunkach międzynarodowych jako potęgi normatywnej, zagadnienie rzadko analizowane w polskiej literaturze. Przybliżenie specyfiki oraz głównych cech potęgi normatywnej zostało dokonane w odniesieniu do pojawiających się kryzysów politycznych, jakimi są umiędzynarodowione konflikty wewnętrzne na terenie: Ukrainy, Mołdawii oraz Kosowa. W literaturze przedmiotu dominują opracowania zawierające deskrypcyjne ujęcie roli Unii Europejskiej w świecie oraz wskazujące podejmowane działania w tym zakresie. Recenzowana publikacja wypełnia pewną lukę w zakresie badań nad sposobami, w jakich Unia Europejska wpływa na podmioty trzecie, zwłaszeza na polityki i działania państw niebędących jej członkami. Czytelnik odnajdzie w niej zarówno rozważania teoretyczne, niezbędne do zrozumienia istoty zagadnienia, jak i zastosowanie omawianych teoretycznych rozważań w praktycznym ujęciu. Porusza aktualne zagadnienia, prezentowane zarówno w ujęciu naukowym, dydaktycznym, jak i popularyzującym wiedzę.

O oryginalności recenzowanej publikacji przesądza kilka wartościowych elementów. Pierwszym z nich jest spoistość opracowania, prezentującego zbiorowe wyniki badań prowadzonych przez zespół kilku autorów, pracowników Instytutu Politologii Uniwersytetu Kardynała Stefana Wyszyńskiego w Warszawie (Katedra Stosunków Międzynarodowych i Studiów Europejskich, Zakład Stosunków Międzynarodowych). Wyniki zostały uporządkowane oraz poprzedzone częścią teoretyczno-metodologiczną. W efekcie powstała spójna monografia.

Po drugie, prowadzona analiza nie ma jedynie na celu uświadomienie czytelnikowi, jak Unia funkcjonuje w relacjach zewnętrznych. Deskrypcja jest jedynie tłem dla dominującej analizy prowadzonej w dwóch płaszczyznach: teoretycznej i empirycznej. W płaszczyźnie teoretycznej analiza dotyczy weryfikacji rozważań, czy badana polityka zewnętrzna Unii Europejskiej ma charakter normatywny i jakie są komponenty tej strategii oraz czy zachodzi europeizacja państw nie członkowskich Unii Europejskiej za pomocą europejskich norm politycznych. Natomiast w płaszczyźnie empirycznej poszukiwania dotyczą warunków skuteczności polityki zewnętrznej Unii Europejskiej jako potęgi normatywnej.

Po trzecie, oceniana publikacja wypełnia ważną lukę w rynku wydawniczym, jaką jest brak spójnej monografii, porządkującej i wyjaśniającej wspomniane wyżej zagadnienia. Jednocześnie stosuje do tego najnowsze podejścia teoretyczne, objaśniając je na tle dotychczasowego kanonu rozumowania, postrzegania stosunków międzynarodowych oraz pełnionych ról przez aktywnych graczy na światowej scenie. W jednym z rozdziałów książki w części teoretycznej przedstawione zostały podstawy koncepcyjne postrzegania Unii Europejskiej jako potegi normatywnej. Nie dokonano tego w sposób opisowy, określając pewne cechy, lecz zmusza się czytelnika do uważnej lektury i zastanowienia się nad powstającymi różnicami w sposobie postrzegania, przyczynami ich powstawania oraz kwestią relewantności kryteriów, które służą do wyboru określonych instrumentów i celów, stosowanych do oceny postrzeganej rzeczywistości.

Po czwarte, kolejną wartością tej pracy, jest wpisanie się w trend narastający, w ostatnich latach, liczby publikacji stosujących założenia konstruktywizmu, co umożliwia analizowanie Unii Europejskiej w kategoriach potęgi normatywnej. Wśród autorów polskojęzycznych prac do pionierów tego trendu należy zaliczyć D. Milczarka (Milczarek, 2001; 2003), opisującego w swoich artykułach pojawiające się nowe podejście badawcze, T. G. Grosse, który dokonał we- 
ryfikacji potęgi normatywnej UE na przykładzie EPS (Grosse, 2010). Jedną z bardziej współczesnych analiz dotyczących podobnego problemu jest artykuł B. Piskorskiej (Piskorska, 2013). Więcej prac jest w językach obcych.

Kolejnym walorem prezentowanej książki jest jej aspekt dydaktyczny. Na szczególną uwagę zasługują precyzyjne rozważania dotyczące zasadności doboru teorii i metod badawczych. W recenzowanej publikacji dr Anna Skolimowska we wstępie jasno określiła cele, zdefiniowała problemy badawcze oraz postawiła liczne pytania, na które odpowiedź została udzielona w toku pracy. Prawidłowo sformułowane zostały także hipotezy. Całość należy określić wzorcowym planem badawczym.

Ponadto autorzy nie ograniczyli się wyłącznie do prezentacji stosowanych perspektyw badawczych. Została dokonana jasna wykładnia, w jaki sposób kompetencje teoretyczne należy wykorzystać podczas prowadzenia badań. Zestawiono używane podejście z innymi teoriami stosunków międzynarodowych, czyniąc $\mathrm{z}$ tej publikacji wciągającą lekturę napisaną językiem zrozumiałym dla każdego czytelnika, chcącego zapoznać się z omawianymi zagadnieniami.

Monografia zgodnie z założeniami badawczymi została podzielona na dwie części: pierwszą - teoretyczną oraz drugą - empiryczną. Pierwsze rozdziały w części teoretycznej stanowią rozważania o realizowaniu przez Unię Europejską swojej roli jako aktora normatywnego w stosunkach międzynarodowych w wymiarze teoretycznym, strategicznym, instytucjonalnym oraz względem najbliższego otoczenia - państw sąsiedzkich.

Pierwszy rozdział w części teoretycznej, zatytułowany Potega norm w stosunkach międzynarodowych, wprowadza podstawowe pojęcia jak m.in. normy w stosunkach międzynarodowych, prezentuje ewolucję kategorii potega oraz dokonuje typologii strategii polityki zagranicznej wyróżnianych typów potęg. Cały rozdział stosuje komparatystykę w ujęciu jakościowym w celu wydobycia cech różnicujących definiowane pojęcia.

Kolejny rozdział został zatytułowany Charakterystyka roli Unii Europejskiej w stosunkach międzynarodowych. Stosując pojęcia zdefiniowane w rozdziale pierwszym dr A. Skolimowska prezentuje jak w praktyce odnoszą się te teoretyczne rozważania z wcześniejszego rozdziału o potędze normatywnej, o strategii przyjmowanej przez potęgę oraz o instrumentach, które są przez daną potęgę wykorzystywane, do analizowanego przypadku Unii Europejskiej - czyli przez potęgę normatywną.

Trzeci rozdział, został zatytułowany Potega normatywna Unii Europejskiej w relacjach z państwami sqsiedzkimi. W rozdziale tym dokonano analizy aktywności Unii Europejskiej w najbliższym otoczeniu poprzez zbadanie, na ile wpisuje się ona w deklarowaną rolę aktora normatywnego. Autorka udziela odpowiedzi na pytanie, czy wspomniana wyżej rola widoczna jest w polityce Unii Europejskiej względem najbliższego sąsiedztwa? Ponadto podjęta zostaje refleksja nad sposobami oraz skutkami europeizacji państw objętych polityką sąsiedztwa a zwłaszcza Partnerstwem Wschodnim. W badanych relacjach występuje wyjątkowa, w skali stosunków międzynarodowych, strategia relacji regionalnych, w których kategoria siły oraz potęgi materialnej ustępuje miejsca sile ideowej. Rozdział ten zawiera opis instrumentarium metodologicznego do podjęcia badania siły oddziaływania Unii Europejskiej w stosunkach regionalnych oraz uwarunkowania skuteczności tej strategii. Wśród nich znajdują się skale pomiaru oraz rodzaje europeizacji, a także strategie oddziaływania. Jest to bardzo ważny rozdzial, porządkujący i prezentujący całościowo mechanizm oddziaływania Unii Europejskiej jako potęgi normatywnej. W literaturze analitycznej można spotkać jedynie wybrane elementy, potrzebne autorom do zbadania wybranego fragmentu rzeczywistości/działania Unii Europejskiej. Rozdział ten jest niezwykle istotny dla całej pracy, wzbogaca ją i stanowi o wartości naukowej całej publikacji. Ponadto książka zyskuje walor pozycji objaśniającej zagadnienie kompleksowo i w sposób uporządkowany.

Część teoretyczną kończy rozdział zatytułowany Unia Europejska wobec problematyki umiędzynarodowionych konfliktów wewnętrznych. Poświęcony jest on zdefiniowaniu konfliktu 
wewnętrznego oraz roli Unii Europejskiej w zakresie bezpieczeństwa międzynarodowego. W rozdziale tym zgodnie ze wcześniej przybliżonymi założeniami teoretycznymi poddano analizie strategię UE zarządzania konfliktami międzynarodowymi oraz zaprezentowano instrumentarium unijne polityki zewnętrznej w obliczu konfliktu.

W części empirycznej publikacja zawiera trzy rozdziały weryfikujące w praktyce założenia teoretyczne potegi normatywnej Unii Europejskiej w obliczu konfliktu. Pierwszy rozdział z tej części dotyczy Normatywnej polityki zewnętrznej Unii Europejskiej w obliczu konfliktu w Kosowie autorstwa dr. Mariusza Sulkowskiego. Kolejny rozdział nosi tytuł Specyfika normatywnej polityki zewnętrznej Unii Europejskiej w obliczu konfliktu rosyjsko-ukraińskiego i został napisany przez dr. Piotra Bajdę. Natomiast ostatni rozdział nosi tytuł Zaangażowanie Unii Europejskiej w rozwiqzanie konfliktu naddniestrzańskiego autorstwa mgr. Jakuba Pieńkowskiego.

Recenzowaną publikację kończy rozdział zatytułowany Normatywna rola Unii Europejskiej $w$ relacjach międzynarodowych - raport $z$ badania. Autorka nawiązuje w nim do postawionych we wstępie pytań i hipotez badawczych oraz wskazuje w jakim stopniu udało się dokonać ich weryfikacji. Przedstawiono także determinanty warunkujące osiągnięcie postępu i większej efektywności działań podejmowanych przez Unię w badanym obszarze. Jest to walor utylitarny prowadzonych badań, co tylko zwiększa przydatność recenzowanej publikacji dla szerszego kręgu odbiorców.

Autorzy ocenianej publikacji wykazali się erudycja, tak w warstwie faktograficznej, jak i teoretycznej, dowodząc bardzo dobrego rozeznania w podjętej przez siebie problematyce. Lektura książki potwierdza umiejętność dowodzenia własnych racji, jak i prowadzenia polemiki z poglądami innych autorów. Wywód jest precyzyjny i logiczny, co umożliwia prawidłowa konstrukcja publikacji. Istotne dla osiagniętych wyników jest także zastosowanie triangulacji w analizie. Prócz wyciągnięcia wniosków z prowadzonego badania, autorzy opracowali także rekomendacje odnoszące się do oferty Unii Europejskiej dla państw-adresatów jej polityki zewnętrznej.

Podjęty przez Autorów temat jest ważny, tak w płaszczyźnie teoretycznej, jak i poznawczej. Opracowanie ma szanse stanowić istotny wkład do badań nad rolą Unii Europejskiej w obliczu umiędzynarodowionych konfliktów wewnętrznych zarówno w ujęciu teoretycznym, dydaktycznym, jak i utylitarnym oraz popularyzującym wiedzę naukową.

MARTA WITKOWSKA 